\title{
PROFIL PENDERITA KONDILOMA AKUMINATA DI POLIKLINIK KULIT DAN KELAMIN RUMAH SAKIT PERTAMINA BINTANG AMIN PERIODE JANUARI 2016 SAMPAI DESEMBER 2019
}

\author{
Arif Effendi ${ }^{1}$, Ratna Purwaningrum ${ }^{2 *}$, Muhammad Syafei \\ Hamzah $^{3}$, Aland Maulana ${ }^{4}$
}

\begin{abstract}
1Departemen Kulit dan kelamin Fakultas Kedokteran Universitas Malahayati ${ }^{2}$ Departemen Histologi Fakultas Kedokteran Universitas Malahayati ${ }^{3}$ Departemen Kulit dan kelamin Rumah Sakit Abdul Moeloek Bandar Lampung ${ }^{4}$ Program Studi Kedokteran Fakultas Kedokteran Universitas Malahayati
\end{abstract}

Email Koresponden: alandmaulana149@gmail.com

\begin{abstract}
PROFILE OF CONDILOMA AKUMINATA PATIENTS IN THE SKIN AND SEX POLYCLINIC OF PERTAMINA BINTANG AMIN HOSPITAL FOR THE PERIOD OF JANUARY 2016 TO DECEMBER 2019.
\end{abstract}

Introduction: Sexually transmitted infection (STI) is one of the diseases and causes of health, social and economic problems in many countries. According to WHO, more than 1 million sexually transmitted infections are acquired every day in various parts of the world and more than 290 million women have human papillomavirus infection. In America, data from the CDC shows new cases with more than 19.7 million sexually transmitted infections each year, and about 14.1 million cases are human papillomavirus infections.

Objective: This study aims to find out information about the profile of condyloma acuminata sufferers at the Dermatology and Venereology Polyclinic at Pertamina Bintang Amin Hospital for the period January 2016 to December 2019.

Methods: This study used quantitative descriptive analysis with the aim of knowing the profile of patients with condyloma acuminata. Sampling was done by using the total sampling method. The sample in this study were patients with condyloma acuminata who were treated at the Dermatology and Venereology Polyclinic at Pertamina Bintang Amin Hospital for the period January 2016 to December 2019 totaling 22 patient medical records.

Results: It was found that patients with condyloma acuminata were more commonly found in the age group of 26 to 35 years (early adulthood), as many as 9 patients (40.9) in the female sex, namely 17 patients (77.3\%) with married status. as many as 17 patients (77.3) while based on the management of patients more were given treatment using electric surgery, namely as many as 8 patients (36.4\%).

Conclusion: Patients with condyloma acuminata in order to maintain their health condition, and avoid risk factors that can increase the occurrence of condyloma acuminata, it is hoped that health workers can hold health promotion activities about the prevention of sexually transmitted diseases, especially condyloma acuminata and this research can be used as additional information to develop further research regarding the factors that have not been studied in this study

Keywords: Condyloma acuminata, sexually transmitted infection, HPV 


\section{INTISARI: PROFIL PENDERITA KONDILOMA AKUMINATA DI POLIKLINIK KULIT DAN KELAMIN RUMAH SAKIT PERTAMINA BINTANG AMIN PERIODE JANUARI 2016 SAMPAI DESEMBER 2019.}

Pendahuluan: Infeksi menular seksual (IMS) adalah salah satu penyakit dan penyebab permasalahan kesehatan, sosial dan ekonomi di banyak negara. Menurut WHO, Lebih dari 1 juta infeksi menular seksual didapat setiap hari di berbagai belahan dunia dan terdapat sekitar Lebih dari 290 juta wanita memiliki infeksi human papillomavirus. Di Amerika, data dari CDC terdapat kasus baru dengan jumlah lebih dari 19,7 juta infeksi menular seksual tiap tahun, dan sekitar 14,1 juta kasus merupakan infeksi human papillomavirus. Tujuan: Penelitian ini bertujuan untuk mengetahui informasi bagaimana profil penderita kondiloma akuminata di Poliklinik Kulit dan Kelamin Rumah Sakit Pertamina Bintang Amin periode Januari 2016 s.d Desember 2019.

Metode: Penelitian ini menggunakan analisis deskriptif kuantitatif dengan tujuan untuk mengetahui profil penderita kondiloma akuminata. Pengambilan sampel dilakukan dengan mengunakan metode total sampling. Sampel dalam penelitian ini adalah pasien penderita kondiloma akuminata yang berobat ke Poliklinik Kulit dan Kelamin Rumah Sakit Pertamina Bintang Amin periode Januari 2016 s.d Desember 2019 yang berjumlah 22 data rekam medik pasien. Hasil penelitian: Didapatkan bahwa penderita kondiloma akuminata lebih banyak ditemukan pada kelompok usia 26 s.d 35 tahun (masa dewasa awal) yaitu sebanyak 9 pasien $(40,9)$ pada jenis kelamin perempuan yaitu sebanyak 17 pasien $(77,3 \%)$ dengan status sudah menikah sebanyak 17 pasien $(77,3)$ sedangkan berdasarkan penatalaksanaan pasien lebih banyak diberi penatalaksanaan dengan menggunakan bedah listrik yaitu sebanyak 8 pasien $(36,4 \%)$.

Kesimpulan: Penderita kondiloma akuminata agar menjaga kondisi kesehatan, dan menghindari faktor risiko yang dapat meningkatkan terjadinya kondiloma akuminata, diharapkan petugas kesehatan dapat mengadakan kegiatan promosi kesehatan tentang pencegahan terhadap penyakit menular seksual khususnya kondiloma akuminata dan penelitian ini dapat dijadikan tambahan informasi untuk mengembangkan penelitian lebih lanjut mengenai faktor-faktor yang belum diteliti dalam penelitian ini

Kata Kunci : Kondiloma akuminata, infeksi menular seksual, HPV 


\section{PENDAHULUAN}

Infeksi menular seksual (IMS) adalah salah satu penyakit dan penyebab permasalahan kesehatan, sosial dan ekonomi di banyak negara. Menurut (WHO, 2019), Lebih dari 1 juta infeksi menular seksual (IMS) didapat setiap hari di berbagai belahan dunia dan terdapat sekitar Lebih dari 290 juta wanita memiliki infeksi human papillomavirus. Di Amerika, data dari Center for Disease Control and Prevention terdapat kasus baru dengan jumlah lebih dari 19,7 juta infeksi menular seksual (IMS) tiap tahun, dan sekitar 14,1 juta kasus merupakan infeksi human papillomavirus. Di Indonesia, prevalensi kondiloma akuminata merupakan penyakit menular seksual terbesar ke tiga dan selalu bertambah setiap tahunnya(Ratnasari, 2018). Data Insiden dan prevalensi kondiloma akuminata di Indonesia sangat beragam. Badan Pusat Statistik Provinsi Lampung menjelaskan bahwa, pada tahun 2015 diketahui ada 632 kasus penyakit IMS (infeksi menular seksual) di kota Bandar Lampung.

Pada sebagian besar infeksi tidak menimbulkan gejala bahkan sembuh sendiri dan infeksi HPV yang berkepanjangan dapat menyebabkan kanker pada leher rahim, kanker anogenital, kanker orofaring, dan kutil kelamin pada pria dan wanita (Markowitz et al., 2014).

Penyakit kondiloma akuminata adalah salah satu penyakit infeksi menular seksual karena diketahui 98\% penularan melalui hubungan seksual dan sisanya dapat ditularkan melalui barang yang terpapar partikel (formites) human papillomavirus dengan masa inkubasi 3 minggu sampai dengan 8 bulan, bahkan sampai dengan 18 bulan (Menaldi, 2017; PERDOSKI, 2017). Diketahui terdapat lebih dari
100 genotipe human papillomavirus yang telah dikenal, dan sekitar 40 genotipe yang dapat menginfeksi alat reproduksi manusia. Diketahui bahwa tipe 11 dan 6 lebih sering terbukti menyebabkan kondiloma akuminata. Banyak orang yang terinfeksi human papillomavirus tidak menunjukkan gejala tetapi masih dapat menularkan infeksi kepada orang lain (Dara Grennan, 2019). Tipe 18 dan 16 merupakan genotipe HPV yang paling sering menimbulkan keganasan dan sering dijumpai pada kanker serviks.

Dalam penelitian yang dilakukan oleh (Saputra, 2020) menyatakan bahwa beberapa penelitian yang telah dilakukan terkait karakterstik kasus kondiloma akuminata didapatkan sebaran kasus sebagian besar berada pada kisaran usia 20 hingga 45 tahun, kemudian distribusi frekuensi berdasarkan jenis kelamin, diketahui perempuan lebih tinggi dibandingkan laki-laki, namun ada penelitian yang menyebutkan bahwa jenis kelamin laki-laki lebih banyak dibandingkan perempuan (Hernisa, 2017). Efloresensi dari kondiloma akuminata biasanya timbul papul atau plak verukosa atau keratotik, soliter atau multipel.

Faktor risiko yang mempengaruhi angka kejadian kondiloma akuminata adalah aktivitas seksual, seperti mempunyai pasangan lebih dari 1 orang (multiple), kehamilan, riwayat IMS, merokok dan penurunan daya tahan tubuh juga akan mempermudah terjadinya infeksi kondiloma akuminata (Aprilianingrum, 2006).

Kondiloma akuminata ini biasanya terdapat di daerah lipatan yang lembab, seperti di daerah genitalia eksterna. Pada laki-laki biasanya terdapat di daerah perineum, sekitar anus, glans penis, sulcus coronarius penis, corpus penis, pangkal penis bahkan di 
dalam meatus uretra. Jika pada perempuan biasanya pada daerah vulva, introitus vagina, dan terkadang pada porsio uteri. Kondiloma akuminata sering terjadi tanpa menimbulkan keluhan namun dapat disertai gatal. Bila terjadi infeksi sekunder kondiloma akuminata ini dapat menimbulkan bau tak sedap, rasa nyeri dan mudah berdarah (Menaldi,2017).

HASIL

Penelitian ini dilakukan pada pasien penderita kondiloma akuminata yang berobat ke Poliklinik Kulit dan Kelamin Rumah Sakit Pertamina Bintang Amin periode Januari 2016 s.d Desember 2019.

\section{Analisa Univariat}

\begin{tabular}{lll}
\multicolumn{2}{c}{ Analisis univariat dalam } \\
penelitian ini dilakukan untuk \\
menilai dan mengetahui
\end{tabular}

\section{METODE}

Penelitian ini menggunakan analisis deskriptif kuantitatif. Pengambilan sampel dilakukan dengan teknik total sampling. Sampel dalam penelitian ini adalah merupakan pasien penderita kondiloma akuminata yang berobat ke Poliklinik Kulit dan Kelamin Rumah Sakit Pertamina Bintang Amin periode Januari 2016 s.d Desember 2019 yang memenuhi kriteria pengambilan sampel, berjumlah 22 sampel.

Data penelitian yang digunakan adalah data sekunder, diambil dengan memperhatikan kriteria inklusi dan kriteria eksklusi, didapatkan jumlah sampel sebanyak 22 sampel. Hasil penelitian dapat dilihat pada tabel dibawah ini.

karakteristik responden penelitian pada masing-masing variabel. Hasil analisis ini nantinya akan memberikan gambaran dari masingmasing variabel yang diteliti.

Tabel 1. Distribusi penderita kondiloma akuminata berdasarkan usia di RSPBA periode 2016 s.d 2019

\begin{tabular}{ccc}
\hline Usia & Jumlah & Persentase \\
\hline 17-25 Tahun & 8 & $36.4 \%$ \\
26-35 Tahun & 9 & $40.9 \%$ \\
36-45 Tahun & 4 & $18.2 \%$ \\
46-55 Tahun & 1 & $4.5 \%$ \\
\hline Total & 22 & $100.0 \%$ \\
\hline
\end{tabular}

Berdasarkan tabel 1 diatas menunjukan bahwa distribusi insidensi penderita kondiloma akuminata menurut usia, didapatkan 9 pasien $(40,9 \%)$ pada kelompok usia 26-35 tahun (masa dewasa awal) kemudian sebanyak 8 pasien $(36,4 \%)$ pada kelompok usia 17 s.d 25 tahun (masa remaja akhir), 4 pasien $(18,2 \%)$ pada kelompok usia 36 s.d. 45 tahun (masa dewasa akhir), dan 1 pasien (4.5\%) pada kelompok usia 46 s.d 55 tahun(masa lansia awal). 
Tabel 2. Distribusi penderita kondiloma akuminata berdasarkan jenis kelamin di RSPBA periode 2016 s.d 2019

\begin{tabular}{ccc}
\hline Jenis kelamin & Jumlah & persentase \\
\hline Laki - laki & 5 & $22.7 \%$ \\
Perempuan & 17 & $77.3 \%$ \\
\hline Total & 22 & $100.0 \%$ \\
\hline
\end{tabular}

Berdasarkan Tabel di atas memperlihatkan distribusi insidensi penderita kondiloma akuminata menurut jenis kelamin, dimana 17 pasien $(77,3 \%)$ berjenis kelamin perempuan dan 5 pasien $(27,7 \%)$ berjenis kelamin laki-laki yang jumlahnya 5 pasien $(27,7 \%)$.

Tabel 3. Distribusi penderita kondiloma akuminata berdasarkan pernikahan di RSPBA periode 2016 s.d 2019

\begin{tabular}{ccc}
\hline Status pernikahan & Jumlah & Persentase \\
\hline Belum menikah & 5 & $22.7 \%$ \\
Menikah & 17 & $77.3 \%$ \\
\hline Total & 22 & $100.0 \%$ \\
\hline
\end{tabular}

Pada tabel diatas dapat dilihat bahwa distribusi insidensi penderita kondiloma akuminata menurut status pernikahan didapatkan 17 pasien $(77,3 \%)$ yang sudah menikah dan 5 pasien $(22,7 \%)$ belum menikah.

Tabel 4. Distribusi penderita kondiloma akuminata berdasarkan penatalaksanaan di RSPBA periode 2016 s.d 2019

\begin{tabular}{ccc}
\hline Penatalaksanan & Jumlah & Persentase \\
\hline Bedah kimia & 5 & $22.7 \%$ \\
Bedah listrik & 8 & $36,4 \%$ \\
Bedah skalpel & 4 & $18,2 \%$ \\
Obat-obatan & 5 & $22,7 \%$ \\
\hline Total & 22 & $100.0 \%$ \\
\hline
\end{tabular}

Berdasarkan pada tabel di atas, penatalaksanaan yang paling banyak digunakan yaitu bedah listrik sebanyak 8 pasien $(36,4 \%)$, diikuti

\section{PEMBAHASAN}

1. Distribusi penderita kondiloma akuminata berdasarkan usia.

Berdasarkan hasil penelitian, didapakan sampel termuda berusia 19 tahun dan sampel tertua berusia 46 tahun. Data yang terbanyak mengalami kondiloma akuminata bedah kimia sebanyak 5 pasien $22,7 \%$ ), obat-obatan sebanyak 5 pasien $(22,7 \%)$, dan terakhir Bedah skalpel sebanyak 4 pasien $(18,2 \%)$.

yaitu pada kelompok usia 26 s.d 35 tahun (masa dewasa awal) yaitu sebanyak 9 pasien (40,9\%), kemudian diikuti kelompok usia 17 s.d 25 tahun (masa remaja akhir) sebanyak 8 pasien $(36,4 \%)$, kelompok usia 36 s.d. 45 tahun (masa dewasa akhir) sebanyak 4 pasien (18,2\%), kelompok 
usia 46 s.d 55 tahun (masa lansia awal) sebanyak 1 pasien (4.5\%). Hasil penelitian ini sejalan dengan hasil penelitian yang dilakukan oleh (Hernisa, 2017) di RSUD dr. H. Abdul Moeloek Bandar Lampung yang menyebutkan bahwa berdasarkan kelompok usia terbanyak yang mengalami kejadian kondiloma akuminata didapatkan pada kelompok usia 20-40 tahun sebanyak 42 orang $(51,9 \%)$.

Kemudian penelitian ini juga sejalan dengan penelitian yang dilakukan oleh (Ida Ayu Ide Nanda Divyani, 2018) di Poliklinik kulit dan kelamin RSUP Sanglah Denpasar periode Januari 2014 s.d April 2015 menyebutkan bahwa kasus kondiloma akuminata berdasarkan umur dengan prevalensi tertinggi yaitu pada kelompok umur 26-45 tahun,yaitu sebanyak 30 orang $(54,5 \%)$.

Namun penelitian ini bertolak belakang dengan hasil penelitian yang dilakukan oleh (Del Amo et al., 2005) yang menyatakan bahwa umur $<20$ tahun berisiko 2,3 kali terkena kondiloma akuminata. $\mathrm{Hal}$ ini disebabkan variabel umur $<20$ tahun dipengaruhi oleh variabel lain yang lebih kuat dalam analisis penelitian ini. Pada dasarnya setiap orang yang sudah aktif secara seksual, beresiko tertular kondiloma akuminata. Prevalensi kondiloma akuminata menurun seiring bertambahnya usia disebabkan karena pada usia tua aktivitas seksualnya lebih rendah dari pada usia muda(Ida Ayu Ide Nanda Divyani, 2018). Usia merupakan salah satu faktor yang sangat berperan dalam penularan penyakit infeksi menular seksual. Penderita Infeksi Menular Seksual terbesar adalah kelompok umur produktif dan seksual aktif yaitu usia $>20$ tahun (Muslimin, T. D, dkk.2011).

2. Distribusi penderita kondiloma akuminata berdasarkan jenis kelamin.

Distribusi

penderita

kondiloma akuminata berdasarkan jenis kelamin ditemukan bahwa jenis kelamin perempuan lebih banyak menderita kondiloma akuminata yaitu 17 pasien $(77,3 \%)$ dibandingkan dengan laki-laki yang jumlahnya 5 pasien (27,7\%). Hasil ini serupa dengan penelitian yang telah dilakukan oleh (Fathurahmad, Suling dan Kapantow, 2018) di RSUP Prof. Dr. R. D. Kandou Manado yang menyebutkan bahwa distribusi penderita kondiloma akuminata paling banyak didapatkan pada perempuan yaitu sebanyak 25 orang $(62,5 \%)$ dari jumlah keseluruhan penderita kondiloma akuminata sebanyak 40 orang, sedangkan pada laki-laki didapatkan penderita sebanyak 15 orang (37,5\%).

Hal tersebut mungkin disebabkan karena organ genitalia perempuan lebih lembab dan luas, vaskularisasinya banyak, serta permukaan mukosa yang lebih tipis sehingga akan lebih rentan terkena mikroabrasi dan penularan virus dari pasangan seksual yang terinfeksi human papillomavirus dengan mudah untuk masuk ke dalam lapisan sel basal (Castle.EP,2014).

3. Distribusi penderita kondiloma akuminata berdasarkan status pernikahan.

$$
\text { Distribusi penderita }
$$

kondiloma akuminata menurut status pernikahan dalam penelitian ini ditemukan bahwa kondiloma akuminata lebih sering terjadi pada pasien dengan status sudah menikah dibandingkan dengan pasien yang belum menikah, yaitu sebanyak 17 orang $(77,3)$ yang sudah menikah dan 5 orang $(22,7 \%)$ orang yang belum menikah.

Hasil penelitian ini sejalan dengan penelitian retrospektif yang pernah dilakukan oleh (Hernisa, 2017) di 
RSUD DR. H. Abdul Moeloek Bandar Lampung yang menyatakan bahwa penderita kondiloma akuminata lebih banyak terjadi pada pasien dengan status sudah menikah dengan jumlah 62 pasien $(76,5 \%)$, dan belum menikah sebanyak 19 pasien $(23,5 \%)$. Hasil penelitian dengan teori yang dikemukakan oleh Wen tahun 1999, dan Amo tahun 2005 yang menyatakan bahwa orang dengan status kawin berisiko terinfeksi kondiloma akuminata 3 kali lebih besar, terutama orang yang memiliki multipartner pasangan seksual( Del Amo et al., 2005; Wen et al., 1999).

Namun hasil penelitian ini bertolak belakang dengan penelitian yang dilakukan oleh (Aprilianingrum, 2006) yang menyebutkan bahwa status perkawinan tidak terbukti sebagai faktor risiko kondiloma akuminata, perbedaan ini disebabkan oleh responden sebagian telah bercerai atau bahkan yang berstatus menikah hayalah sekedar status.

Status pernikahan seseorang mempengaruhi pola penyebaran Infeksi menular seksual melalui hubungan seksual sehingga orang yang telah menikah terutama yang sering bergonta-ganti pasangan seksual memiliki risiko terkena kondiloma akuminata(Hernisa, 2017). Semakin banyak faktor risiko yang mendukung, maka akan semakin cepat terjadinya infeksi kondiloma akuminata pada orang tersebut. Oleh karena itu, himbauan untuk seluruh masyarakat bagi orang yang belum menikah untuk tidak melakukan hubungan seksual dan khusus bagi orang yang sudah menikah untuk setia kepada pasangannya, menjaga kebersihan dan kesehatan organ genitalia dan bagi seseorang yang melakukan hubungan seksual khusunya dengan multipatner harus selalu menggunakan alat kontrasepsi seperti kondom dan memeriksakan kedaannya sedini mungkin dengan screening penyakit Infeksi menular seksual di fasilitas kesehatan terdekat agar dapat dilakukan penanganan sedini mungkin dan tidak terjadi proses penularan.

4. Distribusi penderita kondiloma akuminata berdasarkan penatalaksanaan.

Dari hasil penelitian, penatalaksanaan yang terbanyak digunakan yaitu bedah listrik sebanyak 8 pasien $(36,4 \%)$, diikuti bedah kimia sebanyak 5 pasien $22,7 \%$ ), obat-obatan sebanyak 5 pasien $(22,7 \%)$, dan terakhir bedah skalpel sebanyak 4 pasien(18,2\%).

Modalitas terapi dewasa ini kebanyakan berdasarkan pengalaman empiris dengan tujuan menghancurkan lesi secara fisik atau kimia. Pemilihan obat berdasarkan keadaan pasien seperti, jumlah, ukuran, dan bentuk, serta lokasi lesi. Menurut Panduan Praktik Klinis (PERDOSKI, 2017) Cara pengobatan dapat dibagi atas pengobatan yang dilakukan oleh pasien dan pengobatan oleh dokter di sarana pelayanan kesehatan. Pengobatan yang dapat diaplikasikan sendiri oleh pasien seperti podofilox $0,5 \%$ solusio atau gel, imiquimod $5 \% \mathrm{krim}$, atau sinecathecin $\quad 5 \% \quad$ ointment. Sedangkan yang dilakukan disarana kesehatan seperti Tinctura podofilin $25 \%$, TCA $80-90 \%$, Bedah listrik, Bedah beku, Bedah eksisi/skalpel, dan Laser $\mathrm{CO} 2$.

Terapi bedah berupa bedah listrik dapat diberikan pada semua pasien karena sesuai dengan kepustakaan dikatakan bahwa terapi bedah memiliki keuntungan karena dapat mengeliminasi lesi dalam satu kali kunjungan. Namun, terapi ini membutuhkan latihan, peralatan tambahan dan waktu kunjungan yang lebih lama. Setelah aplikasi anestesi lokal, lesi genital dapat dihilangkan dengan elektrokauter. Perlu 
diperhatikan kedalaman elektrokauter untuk mencegah terjadinya skar. Diketahui terdapat Efikasi sebesar 94\% dan kemungkinan rekurensi 23\% (PERDOSKI, 2017). Dari hasil penelitian ini juga diketahui bahwa penatalaksanaan yang paling sedikit digunakan yaitu dengan menggunakan bedah skalpel atau bedah eksisi dengan data sebanyak 4 pasien(18,2\%). Penatalaksanaan ini dilakukan oleh seorang dokter dan diindikasikan untuk lesi yang sangat besar sehingga menimbulkan obstruksi atau tidak dapat dilakukan terapi dengan cara lainnya. Bedah skalpel juga memiliki efikasi $89-93 \%$ dengan rekurensi 18 s.d 19\% (PERDOSKI, 2017).

\section{KESIMPULAN}

\section{Berdasarkan hasil penelitian Profil Penderita Kondiloma Akuminata Di Poliklinik Kulit Dan Kelamin Rumah Sakit pertamina Bintang Amin Periode Januari 2016 Sampai Desember 2019, maka dapat disimpulkan:}

1. Berdasarkan usia pasien, penderita kondiloma akuminata lebih banyak ditemukan pada kelompok usia 26 s.d 35 tahun (masa dewasa awal) yaitu sebanyak 9 orang $(40,9 \%)$ dan sangat sedikit pada kelompok usia 46 s.d 55 tahun(masa lansia awal) yaitu sebanyak 1 orang (4.5\%).

2. Berdasarkan jenis kelamin pasien, penderita kondiloma akuminata lebih banyak ditemukan pada perempuan yaitu sebanyak 17 pasien (77,3\%) dibandingkan dengan laki-laki yang jumlahnya 5 pasien $(27,7 \%)$.

3. Berdasarkan status pernikahan pasien, penderita kondiloma akuminata lebih banyak ditemukan pada pasien yang sudah menikah sebanyak 17 pasien $(77,3)$ dibandingkan pasien yang belum menikah yaitu sebanyak 5 pasien $(22,7 \%)$.

4. Berdasarkan penatalaksanaan pada pasien, penderita kondiloma akuminata lebih banyak diberi penatalaksanaan dengan menggunakan bedah listrik yaitu sebanyak 8 pasien $(36,4 \%)$ dan sangat sedikit menggunakan bedah skalpel sebanyak 4 pasien(18,2\%).

\section{SARAN}

Hasil penelitian ini dapat digunakan sebagai evidence based dan sumber informasi tentang kondiloma akuminata, dapat menjadi acuan masyarakat khususnya penderita kondiloma akuminata agar menjaga kondisi kesehatan, dan menghindari faktor risiko yang dapat meningkatkan terjadinya kondiloma akuminata, diharapkan petugas kesehatan dapat mengadakan kegiatan promosi kesehatan tentang pencegahan terhadap penyakit menular seksual khususnya kondiloma akuminata dan penelitian ini dapat dijadikan tambahan informasi untuk mengembangkan penelitian lebih lanjut mengenai faktor-faktor yang belum diteliti dalam penelitian ini. 


\section{DAFTAR PUSTAKA}

Aprilianingrum, F. (2006) "Faktor Risiko Kondiloma Akuminata Pada Pekerja Seks Komersial," Journal of Molecular Biology, 301(5), hal. 1163-1178.

Castle EP, Rodriguez CA, Porras C, Herrero $R$, Schiffman $M$, Gonzalez P, et al (2014) “A Comparison of Cervical and Vaginal Human Papillomavirus Philip," NIH Public Access, 23(1), hal. 1-7. doi: 10.1097/OLQ.0b013e318064c8 c5.A.

Dara Grennan, M. (2019) "Genital warts.," Clinical evidence, 321(13).

Del Amo, J. et al. (2005) "Influence of age and geographical origin in the prevalence of high risk human papillomavirus in migrant female sex workers in Spain," Sexually Transmitted Infections, 81(1), hal. 79-84. doi: $10.1136 /$ sti.2003.008060.

Fathurahmad, A., Suling, P. L. dan Kapantow, G. M. (2018) "Profil Kondiloma Akuminata di Poliklinik Kulit dan Kelamin RSUP Prof. Dr. R. D. Kandou Manado Periode Januari 2013 sampai Desember 2013," eCliniC, 6(2), hal. 110-115. doi: 10.35790/ecl.6.2.2018.22115.

Hernisa, M. P. (2017) "Analisis faktor-faktor yang berhubungan dengan kondiluma akuminata di Poliklinik Kulit dan Kelamin RSUD Dr. H. Abdul Moeloek Bandarlampung tahun 2016," Jurnal Ilmu Kedokteran dan Kesehatan, 4(1), hal. 8-11.

Ida Ayu Ide Nanda Divyani, N. R. V. K. (2018) "PROFIL KASUS KONDILOMA AKUMINATA DI POLIKLINIK KULIT DAN KELAMIN RSUP SANGLAH DENPASAR PERIODE JANUARI 2014-APRIL 2015," E-JURNAL MEDIKA,
7(11), hal. 1-5.

Markowitz, L. E. et al. (2014) "Human Papillomavirus Vaccination Recommendations of the Advisory Committee on Immunization Practices (ACIP)," MMWR Recommendations and Reports, 63(1), hal. 1-30.

Muslimin, T. D, dkk.2011. Profil Kondiloma akuminata di RS Akademis Jaury Makasar study Retrospektif.Bagian IImu Kesehatan Kulit dan Kelamin, Fakultas

Kedokteran.Universitas

Hasanudin Periode Oktober 2010-September 2011.

Patel, R. V., Yanofsky, V. R. dan Goldenberg, G. (2012) "Genital warts: A comprehensive review," Journal of Clinical and Aesthetic Dermatology, 5(6), hal. 25-36.

PERDOSKI (2017) PANDUAN PRAKTIK KLINIS. Diedit oleh T. P. dan Editor dan F. Dr. dr. Sandra Widaty, Sp.KK(K), FINSDV, FAADV Prof. Dr. dr. Hardyanto Soebono, Sp.KK(K), FINSDV, FAADV dr. Hanny Nilasari, Sp.KK(K), FINSDV, FAADV Dr. dr. M. Yulianto Listiawan, Sp.KK(K), FINSDV, FAADV dr. Agnes Sri Siswati, Sp.KK(K), FINSDV, FAADV dr. Jakarta. doi: $10.1021 /$ jo900140t.

Putri, S. A. H. (2017) "PROFIL PENDERITA KONDILOMA AKUMINATA DI RS WAHIDIN SUDIROHUSODO MAKASSAR STUDI Siti Aisyah Hamzakir Putri Pembimbing: dr . Alwi A . Mappiasse , Sp . KK, Ph . D.

Ratnasari, D. T. (2018) "Kondiloma Akuminata Condyloma Accuminatum," Ilmiah Kedokteran Wijaya Kusuma, 5(2), hal. 18-21.

Saputra, N. (2020) "Karakteristik Kejadian Kasus Kondiloma 
Akuminata di Indonesia," Muhammadiyah Journal of Midwifery, 1(1), hal. 25. doi: 10.24853/myjm.1.1.25-29.

Wen, L. M. et al. (1999) "Risk factors for the acquisition of genital warts: Are condoms protective?," Sexually Transmitted Infections, 75(5), hal. 312-316. doi: 10.1136/sti.75.5.312.

WHO (2019) "Sexually Transmitted Infections," Sexually transmitted infections, hal. 415-426. doi: 10.1002/9781444311662.ch40.

Workowski, K. A. dan Bolan, G. A. (2015) Sexually transmitted diseases treatment guidelines, 2015,

Recommendations MMWR

Reports. and $10.1016 / j$ annemergmed 2015 .07.526. 